
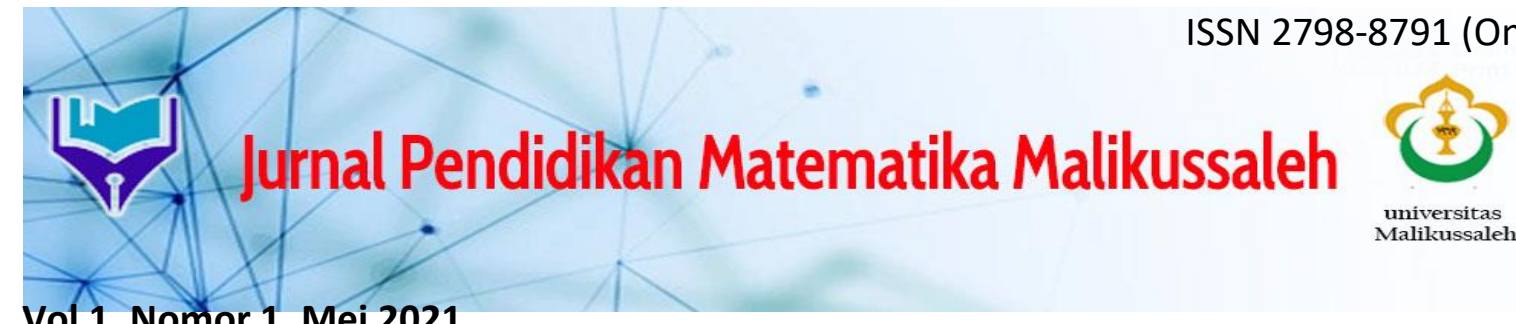

Vol 1, Nomor 1, Mei 2021

\title{
PENGARUH MODEL PEMBELAJARAN LEARNING CYCLE 5E TERHADAP KEMAMPUAN KOMUNIKASI MATEMATIS SISWA SMA NEGERI 1 SIMPANG MAMPLAM
}

\author{
Safrina $^{1)}$, Muliana ${ }^{2) *}$, Aklimawati ${ }^{3)}$ \\ ${ }^{1,2,3}$ Prodi Pendidikan Matematika, Universitas Malikussaleh, Aceh Utara, Indonesia \\ *3)E-mail : Aklimawati@unimal.ac.id
}

\begin{abstract}
Abstrak
Kemampuan komunikasi matemamatis merupakan kemampuan matematis yang harus dikembangkan dalam pendidikan matematika. Untuk itu penggunaan model pembelajaran diharapkan memberi pengaruh terhadap kemampuan komunikasi matematis siswa. Adapun bertujuan untuk mengetahui pengaruh model pembelajaran Learning Cycle 5E terhadap kemampuan komunikasi matematis siswa pada materi barisan. Menggunakan pendekatan kuantitatif dengan jenis penelitian quaisi eksperimen. Populasi seluruh siswa kelas XI SMA Negeri 1 Simpang Mamplam sedangkan sampel yang diambil adalah kelas XI IPA2 sebagai kelas eksperimen dan kelas XI IPA3 sebagai kelas kontrol. Rancangan penelitian yang digunakan adalah Nonequivalent Control Group Post-test Only Design. Hasil penelitian sesuai dengan dasar pengambilan keputusan uji Non Parametrik Mann-Whitney jika nilai Asymp.Sig < 0,05 maka H0 ditolak dan jika nilai Asymp.Sig > 0,05 maka H0 diterima maka di peroleh hasil signifikan sebesar $0,000<0,05$ sehingga dapat disimpulkan bahwa ada pengaruh model pembelajaran Learning Cycle 5E terhadap kemampuan matematis siswa pada materi Barisan apabila dibandingkan dengan pembelajaran saintifik.
\end{abstract}

Kata kunci: Model Pembelajaran Learning cycle 5E, Kemampuan Komunikasi Matematis Siswa.

\section{PENDAHULUAN}

Matematika merupakan ilmu universal yang mendasari perkembangan teknologi modern serta memiliki kemampuan penting dalam berbagai disiplin ilmu (Ibrahim \& Suparni, 2008). Matematika dapat mengembangkan daya pikir manusia, membekali siswa memiliki kemampuan berpikir logis, kritis, sistematis, analitis, dan kreatif (Burais et al., 2016). Penguasaan matematika yang kuat sejak dini diperlukan siswa untuk menguasai dan menciptakan teknologi dimasa depan (Masitoh \& Prabawanto, 2016). Oleh karena itu, mata pelajaran matematika perlu diajarkan disetiap jenjang pendidikan guna mengembangkan kemampuan menggunakan bahasa matematika dalam mengkomunikasikan ide atau gagasan matematika untuk memperjelas suatu keadaan atau masalah. Dengan demikian, matematika menjadi ilmu yang sangat penting dalam kehidupan manusia karena pembelajaran matematika harus mampu menuntut dan membangun keterampilan siswa yang dapat menjawab permasalahan mendatang. 

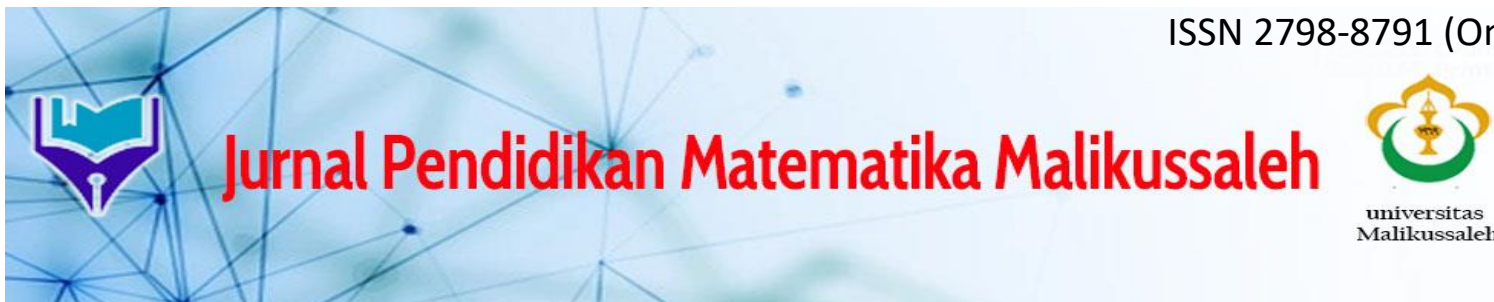

Vol 1, Nomor 1, Mei 2021

Berdasarkan tujuan pembelajaran matematika yang terdapat dalam (NCTM, 2000) dan (Permendikbud, 2018) jelas terlihat bahwa kemampuan komunikasi matematis merupakan salah satu kemampuan penting yang harus dikembangkan dalam diri siswa. Komunikasi merupakan suatu proses penyampain informasi atau gagasan dari seseorang kepada orang lain secara lisan maupun tulisan. Menurut Ramella komunikasi matematis yaitu kemampuan untuk mengekpresikan ide-ide matematika secara koheren kepada teman, guru, dan lainnya melalui bahasa lisan tulisan. Mahmudi juga mengemukakan bahwa kemampuan komunikasi matematis adalah kemampuan untuk mengekspresikan ide-ide dan pemahaman matematika secara lisan dan tulisan menggunakan bilangan, simbol, gambar, grafik, diagram atau katakata.

Komunikasi merupakan kemampuan yang sangat penting dalam kegiatan pembelajaran dan harus dikembangkan. Withim menyatakan bahwa kemampuan komunikasi menjadi penting ketika diskusi antara siswa dilakukan, sehingga siswa diharapkan mampu menyatakan dan bekerja sama (Apiyati, 2016).

Faktanya kemampuan komunikasi matematis di Indonesia masih tergolong rendah. Hal ini diketahui dari survei Programme for International Student Assessment (PISA) (PISA, 2012). Kemampuan-kemampuan yang diuji pada PISA sangat berkaitan erat dengan indikator-indikator kemampuan komunikasi matematis. Kemampuan tersebut meliputi kemampuan untuk berargumentasi dan menarik kesimpulan yang termasuk dalam indikator kemampuan komunikasi matematis bagian dari Written (menulis), memberikan alasan secara matematis termasuk indikator kemampuan komunikasi matematis bagian mathematical expression (ekspresi matematika), menyelesaikan soal berupa gambar dan menginterpretasikan permasalahan dalam berbagai situasi termasuk dalam indikator kemampuan komunikasi matematis bagian drawing (menggambar). Dari survei serta pemaparan tersebut, menunjukkan bahwa kemampuan komunikasi matematis siswa di indonesia masih tergolong rendah, sehingga perlu adanya upaya untuk meningkatkan kemampuan komunikasi matematis dan upaya ini diharapkan nantinya membawa dampak yang baik terhadap pendidikan Indonesia.

Selain itu walaupun sumber belajar yang digunakan sudah berbasis kurikulum 2013 dan pendekatan saintifik namun guru pada umumnya masih cenderung aktif sehingga pembelajaran belum berpusat pada siswa (student centered learning). Siswa menerima materi yang disampaikan oleh guru dengan aktif mencatat tanpa ada satupun yang mengajukan pendapat atau bertanya secara lisan terkait dengan materi tersebut. siswa juga tidak aktif dalam menyampaikan ide-ide penyelesaian masalah matematika. siswa masih sukar dalam menyusun bukti dan memberikan alasan terhadap solusi permasalahan yang ada. Siswa saat menjawab soal cenderung berpatokan pada langkah penyelesaian dari contoh soal sehinga terdapat miskomunikasi antara soal dengan siswa. Siswa sukar dalam mengubah bentuk uraian kedalam model matematika sehingga siswa sulit menentukan rumus dengan cepat dan tepat dalam menyelesaikan masalah. Siswa juga sukar untuk menemukan pola dan sifat dari gejala matematis.

Dari uraian di atas diketahui permasalahan tentang kemampuan komunikasi matematis siswa menjadi permasalahan serius yang harus ditangani. Oleh karenanya dibutuhkan alternatif penggunaan suatu model pembelajaran yang dapat mengembangkan kemampuan komunikasi matematis siswa. Salah satu model pembelajaran yang dapat memberikan 

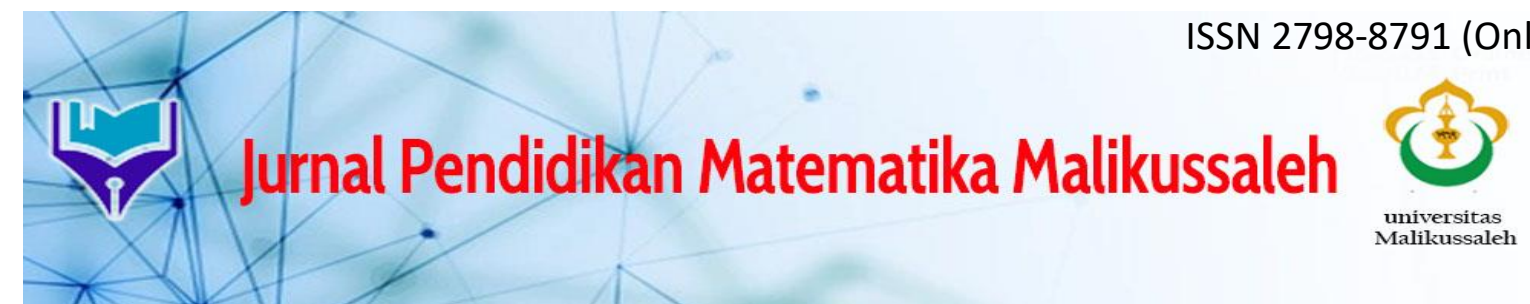

Vol 1, Nomor 1, Mei 2021

kesempatan kepada siswa untuk mengoptimalkan cara belajar dan mengembangkan daya nalar sehingga juga dapat meningkatkan kemampuan komunikasi matematis adalah model pembelajaran Learning Cycle 5E.

Bybee mengemukakan bahwa model Learning Cycle merupakan model pembelajaran yang berlandaskan teori kontruktivisme dimana anak akan membangun pengetahuannya sendiri dengan cara mengaitkannya dengan pengalaman sebelumnya yang pernah didapatkan sehingga diharapkan proses pembelajaran akan berpusat pada siswa (student centered)(Tuna \& Kacar, 2013). Model Learning Cycle adalah suatu model pembelajaran yang berpusat pada pebelajar (student centered) sehingga siswa dapat lebih aktif dan mandiri dalam kegiatan pembelajaran (Kulsum \& Hindarto, 2011).

Kegiatan pembelajaran yang dilakukan dalam model pembelajaran Learning Cycle 5E dapat mendorong siswa untuk meningkatkan minat, keaktifan, semangat belajar dan kerjasama mereka di kelas sehingga kemampuan komunikasi matematis siswa dapat meningkat.

Berdasarkan uraian di atas, penelitian ini ingin menjawab permasalahan, Apakah terdapat perbedaan kemampuan komunikasi matematis siswa yang diberi model pembelajaran Learning Cycle 5E dengan siswa yang diberi pembelajaran dengan pendekatan saintifik pada materi Barisan kelas IX SMA Negeri 1 Simpang Mamplam? Yang hasilnya diharapkan dapat bermanfaat khususnya bagi guru matematika sebagai alternatif metode pembelajaran yang baru dengan penggunaan model yang tepat dan menarik dalam pembelajaran matematika sebagai upaya meningkatkan kemampuan komunikasi matematis siswa.

\section{METODE}

\section{Jenis Penelitian}

Penelitian ini menggunakan pendekatan kuantitatif. Sedangkan jenis penelitian yang digunakan pada penelitian ini yaitu quasi eksperimental design. Rancangan penelitian yang digunakan adalah Nonequivalent Control Group Post-test Only Design.

\section{Waktu dan Tempat Penelitian}

Waktu untuk kegiatan penelitian ini dilaksanakan pada semester genap tahun ajaran 2019/2020. Penelitian ini dilaksanakan di kelas XI SMA Negeri 1 Simpang Mamplam. Sekolah ini beralamatkan di Jl.Medan-Banda aceh, Kecamatan Simpang Mamplam, Kabupaten Bireuen.

\section{Populasi/ Sampel}

Populasi adalah siswa kelas XI SMA Negeri 1 Simpang Mamplam, sedangkan sampel yang dipilih adalah siswa kelas XI IPA2 sebagai kelas eksperimen dan siswa kelas XI IPA3 sebagai kelas kontrol.

\section{Data, Intrumen, dan Teknik Pengumpulan Data}

Instrumen yang digunakan adalah Perangkat pembelajaran adalah sekumpulan sumber belajar yang digunakan dalam proses belajar mengajar. Perangkat pembelajaran yang digunakan dalam penelitian ini berupa Rencana Pelaksanaan Pembelajaran (RPP), Lembar 
Aktivitas Siswa (LAS), buku paket dan juga soal tes. Tes yang digunakan untuk mengetahui kemapuan komunikasi matematis adalah tes uraian yaitu berupa 3 soal yang menuntut siswa untuk menjawab secara rinci, sehingga indikator kemampuan komunikasi, ketelitian dan sistematis penyusunan dapat dievaluasi.

\section{Teknik Analisis Data}

Data tes kemampuan komunikasi matematis siswa yang diperoleh diolah dan dianalisis untuk dapat menjawab rumusan masalah dan hipotesis penelitian. Data dikelompokkan berdasarkan kelompok yang diajarkan menggunakan model pembelajaran Learning Cycle 5E dan kelompok yang diajarkan menggunakan pembelajaran saintifik. Pengolahan data diawali dengan menguji prasyarat statistik yang diperlukan sebagai dasar dalam pengujian hipotesis, antara lain adalah uji normalitas data dan uji homogenitas. Selanjutnya dilakukan analisis dengan uji-t. Seluruh perhitungan statistik menggunakan bantuan software SPSS 1 dan Program Microsoft Exel.

\section{HASIL DAN PEMBAHASAN}

Hasil analisis data sebelum penelitian meliputi validitas, reabilitas, tingkat kesukarandan daya pembeda. Tujuan dari analisis data ini untuk menguji apakah instrumen tes layak digunakan pada tahap penelitian. Adapun instrumen tes yang diuji sebanyak 6 butir soal yang berbentuk uraian.

Tabel 1. Data Hasil Uji Validitas butir soal

\begin{tabular}{rlllll}
\hline $\begin{array}{l}\text { No } \\
\text { Soal }\end{array}$ & Koef.Korelasi & $\mathrm{t}_{\text {hitung }}$ & $\mathrm{t}_{\text {tabel }}$ & Keterangan & Interpretasi \\
\hline 1 & 0,94 & 11,52 & 1,745 & Valid & Sangat Tinggi \\
\hline 2 & 0,91 & 8,78 & 1,745 & Valid & Sangat Tinggi \\
\hline 3 & 0,86 & 7,03 & 1,745 & Valid & Sangat Tinggi \\
\hline 4 & 0,92 & 9,64 & 1,745 & Valid & Sangat Tinggi \\
\hline 5 & 0,86 & 6,80 & 1,745 & Valid & Sangat Tinggi \\
\hline 6 & 0,18 & 0.73 & 1,745 & Tidak & Sangat Rendah \\
& & & & Valid & \\
\hline
\end{tabular}

\section{Tabel 2. Uji Reliabilitas Butir Soal}

\begin{tabular}{|c|c|c|c|c|c|c|}
\hline Tes & Butir Soal & $\begin{array}{l}\text { Item } \\
\text { per } \\
\text { Soal }\end{array}$ & $\begin{array}{c}\text { Varian } \\
\text { Butir }\end{array}$ & $\begin{array}{l}\text { Varian } \\
\mathrm{s}\end{array}$ & Koef. Reliabilitas & Interpretasi \\
\hline & 1 & 0,61 & & \multirow{5}{*}{36,33} & \multirow{5}{*}{0,88} & \multirow[t]{5}{*}{ Tinggi } \\
\hline & 2 & 1,23 & & & & \\
\hline & 3 & 2,95 & & & & \\
\hline & 4 & 1,38 & & & & \\
\hline & 5 & 3,11 & & & & \\
\hline
\end{tabular}


Vol 1, Nomor 1, Mei 2021

\begin{tabular}{cl}
\hline 6 & 0,36 \\
\hline Jumlah & 9,67 \\
\hline
\end{tabular}

Tabel 3. Hasil Uji Daya Pembeda

\begin{tabular}{ccc}
\hline Nomor Soal & $\begin{array}{c}\text { Indeks Daya } \\
\text { Pembeda }\end{array}$ & Interpretasi \\
\hline 1 & 0,277 & Cukup \\
\hline 2 & 0,291 & Cukup \\
\hline 3 & 0,694 & Baik \\
\hline 4 & 0,361 & Cukup \\
\hline 5 & 0,527 & Baik \\
\hline 6 & $-0,027$ & Jelek \\
\hline
\end{tabular}

Tabel 4. Hasil Uji Tingkat Kesukaran

\begin{tabular}{ccc}
\hline Nomor Soal & Tingkat Kesukaran & Interpretasi \\
\hline 1 & 0,361 & Sedang \\
\hline 2 & 0,529 & Sedang \\
\hline 3 & 0,652 & Sedang \\
\hline 4 & 0,569 & Sedang \\
\hline 5 & 0,736 & Mudah \\
\hline 6 & 0,402 & Sedang \\
\hline
\end{tabular}

Hasil tes kemampuan komunikasi matematis siswa memberikan informasi mengenai kemampuan matematis siswa baik di kelas eksperimen maupun kelas kontrol. Informasi tersebut berupa hasil postest. Berikut ini hasil data deskriptif kemampuan komunikasi matematis siswa.

Tabel 5. Statistik Deskriptif Kemampuan Komunikasi Matematis Siswa Descriptive Statistics

\begin{tabular}{|c|c|c|c|c|c|c|c|}
\hline & \multirow{2}{*}{$\begin{array}{c}\mathbf{N} \\
\begin{array}{c}\text { Stati } \\
\text { stic }\end{array} \\
\end{array}$} & \multirow{2}{*}{$\begin{array}{c}\text { Mini } \\
\text { mum } \\
\begin{array}{c}\text { Statist } \\
\text { ic }\end{array} \\
\end{array}$} & \multirow{2}{*}{$\begin{array}{c}\text { Maxi } \\
\text { mum } \\
\begin{array}{c}\text { Statist } \\
\text { ic }\end{array}\end{array}$} & \multicolumn{2}{|c|}{ Mean } & \multirow{2}{*}{$\begin{array}{c}\begin{array}{c}\text { Std. } \\
\text { Deviation }\end{array} \\
\text { Statistic }\end{array}$} & \multirow{2}{*}{$\begin{array}{c}\begin{array}{c}\text { Varia } \\
\text { nce }\end{array} \\
\begin{array}{c}\text { Statist } \\
\text { ic }\end{array}\end{array}$} \\
\hline & & & & $\begin{array}{l}\text { Stati } \\
\text { stic }\end{array}$ & $\begin{array}{l}\text { Std. } \\
\text { Error }\end{array}$ & & \\
\hline Eksperimen & 20 & 4,00 & 11,00 & $\begin{array}{r}8,70 \\
00 \\
\end{array}$ & ,33325 & 1,49032 & 2,221 \\
\hline Kontrol & 25 & 5,00 & 8,00 & $\begin{array}{r}6,12 \\
00 \\
\end{array}$ & , 18547 & ,92736 & ,860 \\
\hline $\begin{array}{ll}\begin{array}{l}\text { Valid } \\
\text { (listwise) }\end{array} & \mathrm{N} \\
\end{array}$ & 20 & & & & & & \\
\hline
\end{tabular}



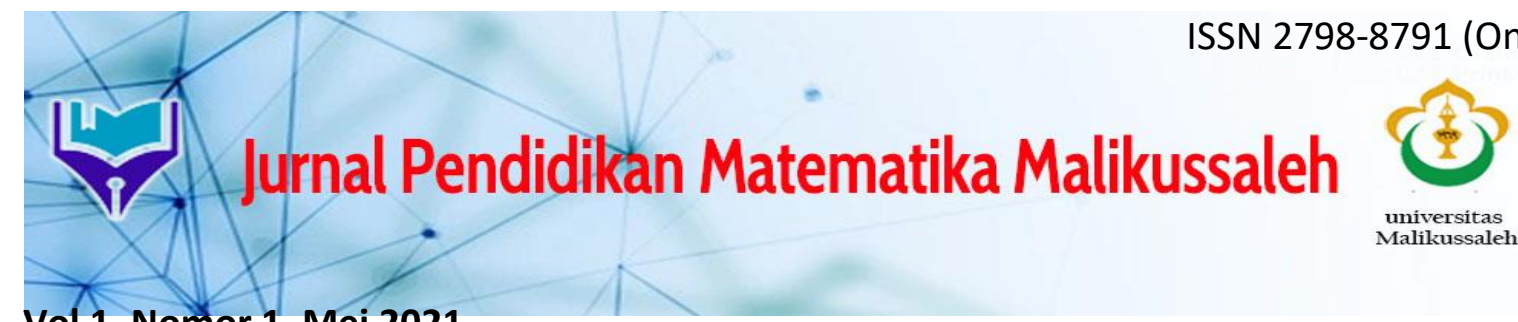

Vol 1, Nomor 1, Mei 2021

Tabel 5 menunjukkan bahwa skor minimum post-test kemampuan komunikasi matematis siswa di kelas eksperimen adalah 4,00, sedangkan di kelas kontrol adalah 5,00, sedangkan untuk skor maksimum kemampuan komunikasi matematis siswa di kelas eksperimen adalah 11,00 dan kelas kontrol adalah 8,00. Rata-rata nilai post-test lebih jelas dapat dilihat pada gambar berikut:

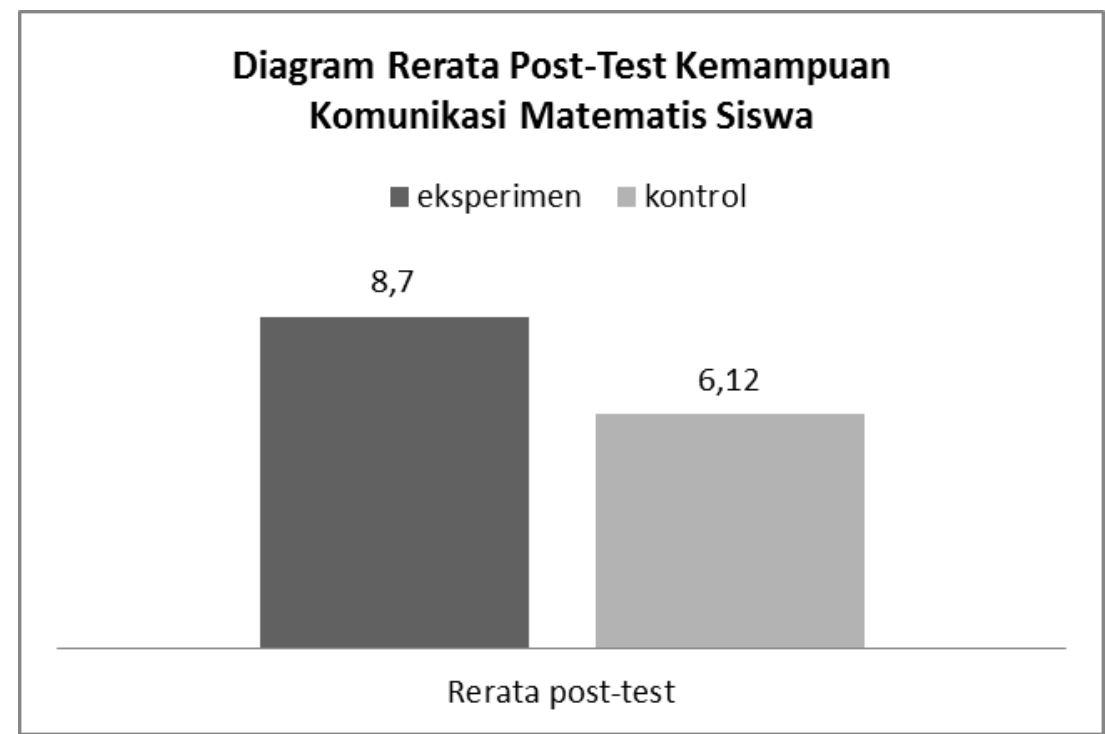

\section{Gambar 1. Diagram Rerata Post-Test Kemampuan Komunikasi Matematis Siswa}

Pada Gambar 1 terlihat bahwa skor rerata post-test kemampuan komunikasi matematis siswa untuk kelas eksperimen $(8,7)$ lebih tinggi dibanding rerata post-test kemampuan komunikasi matematis siswa untuk kelas kontrol $(6,12)$. Standar devisiasi post-test kemampuan komunikasi matematis siswa untuk kelas eksperimen $(1,49032)$ lebih tinggi dibanding standar devisiasi post-test kelas kontrol $(0,92736)$.

Untuk melihat perbedaan kemampuan komunikasi matematis siswa yang memperoleh model pembelajaran learning Cycle $5 E$ dengan siswa yang memperoleh pembelajaran dengan pendekatan saintifik maka perlu di lakukan uji-t terhadap nilai post-test kelas eksperimen dan kelas kontrol. Sebelum melakukan uji-t terlebih dahulu dilakukan uji prasyarat yaitu uji normalitas dan uji homogenitas. Uji normalitas dalam penelitian ini menggunakan uji statistik Saphiro-Wilk. Data hasil uji normalitas ditunjukkan dalam tabel sebagai berikut:

Tabel 6. Hasil Uji Normalitas Menggunakan SPSS 18

\begin{tabular}{|c|c|c|c|c|c|c|c|}
\hline \multicolumn{8}{|c|}{ Tests of Normality } \\
\hline & \multirow[t]{2}{*}{ Kelompok } & \multicolumn{3}{|c|}{ Kolmogorov-Smirnov ${ }^{a}$} & \multicolumn{3}{|c|}{ Shapiro-Wilk } \\
\hline & & Statistic & Df & Sig. & Statistic & Df & Sig. \\
\hline \multirow[t]{2}{*}{ Posttes } & kelas eksperimen &, 230 & 20 &, 007 &, 834 & 20 &, 003 \\
\hline & kelas kontrol & 391 & 25 & 000 & ,718 & 25 & 000 \\
\hline
\end{tabular}



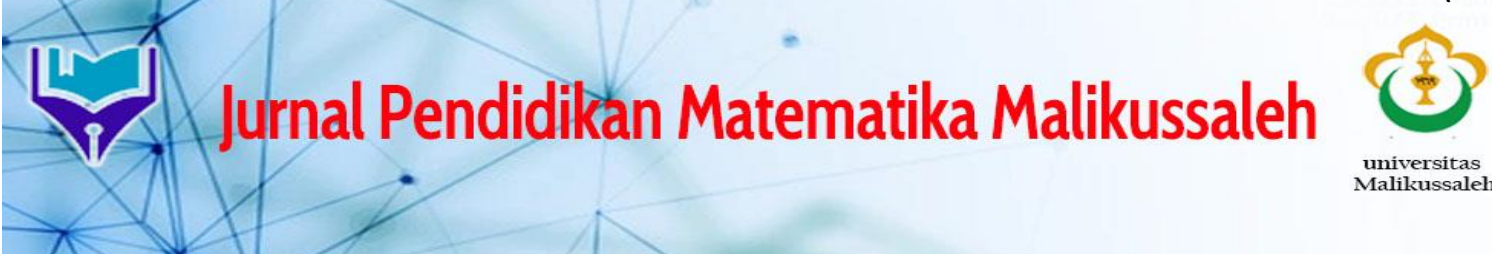

Vol 1, Nomor 1, Mei 2021

Dari table 6 terlihat bahwa nilai signifikan uji normalitas Saphiro-Wilk pada data posttest kemampuan komunikasi matematis siswa dikelas eksperimen adalah 0,003, sedangkan dikelas kontrol adalah 0,000. Berdasarkan ketentuan Jika nilai pada kolom sig. > 0,05 maka $\mathrm{H}_{0}$ diterima.Sehingga dapat disimpulkan bahwa skor post-test kemampuan komunikasi matematis siswa pada kelas eksperimen dan pada kelas kontrol tidak berdistribusi normal.

Setelah melakukan pengujian prasyarat analaisis data, diketahui bahwa normalitas varians data tidak terpenuhi, sehingga analisis data tidak dapat dilanjutkan dengan menggunakan uji-t, melainkan dengan menggunakan uji Non Parametrik Mann-Whitney. Pengujiannya dilakukan dengan menggunakan IMB software SPSS 18. Rangkuman hasil uji Non Parametrik Mann-Whitney disajikan sebagai berikut:

\section{Tabel 7 Hasil Uji Non Parametrik Mann-Whitney Kemampuan Komunikasi Matematis Siswa} Test Statistics $^{\mathrm{a}}$

\begin{tabular}{|l|r|}
\hline & \multicolumn{1}{|c|}{$\begin{array}{c}\text { hasil post- } \\
\text { test }\end{array}$} \\
\hline Mann-Whitney U & 39,000 \\
Wilcoxon W & 364,000 \\
$Z$ & $-4,976$ \\
Asymp. Sig. (2- &, 000 \\
tailed) & \\
\hline
\end{tabular}

a. Grouping Variable: kelas

Pada Tabel 7 hasil perhitungan dengan menggunakan analisis Uji Non Parametrik Mann-Whitney untuk data kemampuan komunikasi matematis siswa diperoleh nilai Asymp.Sig 0,000. Sesuai dengan dasar pengambilan keputusan jika nilai Asymp.Sig $<0,05$ maka Ho ditolak dan jika nilai Asymp.Sig > 0,05 maka Ho diterima.

Adapun pengujiannya dilakukan berdasarkan Hipotesis penelitian yaitu:

$\mathrm{H}_{0}: \mu_{\mathrm{E}}=\mu_{\mathrm{k}}$; tidak terdapat perbedaan kemampuan komunikasi matematis siswa yang diberi model pembelajaran Learning Cycle $5 E$ dengan siswa yang diberi pembelajaran dengan pendekatan saintifik. Dengan kata lain dapat dikatakan bahwa tidak ada pengaruh model pembelajaran Learning Cycle $5 E$ terhadap kemampuan matematis siswa pada materi Barisan apabila dibandingkan dengan pembelajaran saintifik.

$\mathrm{H}_{1}: \mu_{\mathrm{E}} \neq \mu_{\mathrm{k}}$; terdapat perbedaan kemampuan komunikasi matematis siswa yang diberi model pembelajaran Learning Cycle $5 E$ dengan siswa yang diberi pembelajaran dengan pendekatan saintifik. Dengan kata lain dapat dikatakan bahwa ada pengaruh model pembelajaran Learning Cycle $5 E$ terhadap kemampuan matematis siswa pada materi Barisan apabila dibandingkan dengan pembelajaran saintifik.

Berdasarkan output Test Statistica diketahui bahwa nilai Asymp.Sig sebesar 0,000< 0,05. Maka dapat disimpulkan Ho ditolak. Dengan demikian disimpulkan bahwa terdapat 

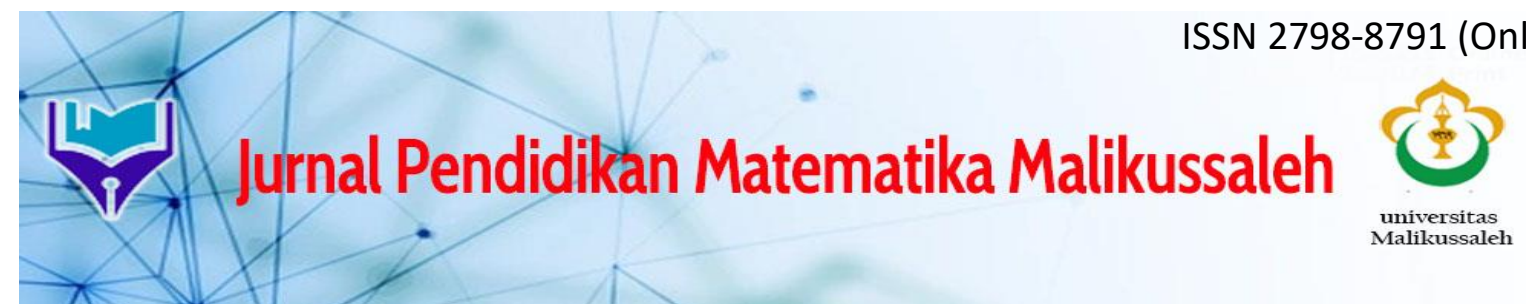

Vol 1, Nomor 1, Mei 2021

perbedaan kemampuan komunikasi matematis siswa yang diberi model pembelajaran Learning Cycle $5 E$ dengan siswa yang diberi pembelajaran dengan pendekatan saintifik. Dengan kata lain dapat dikatakan bahwa ada pengaruh model pembelajaran Learning Cycle $5 E$ terhadap kemampuan matematis siswa pada materi Barisan apabila dibandingkan dengan pembelajaran saintifik.

Pengaruh model pembelajaran dilihat dari adanya perbedaan kemampuan komunikasi matematis siswa antara kelas eksperimen yang diberikan model pembelajaran Learning Cycle $5 E$ dan kelas kontrol yang diberikan pembelajaran dengan pendekatan saintifik. Data penelitian diperoleh dari hasil post-test kemampuan komunikasi matematis siswa. Sedangkan skor post-test diperoleh dari skor masing-masing kelas eksperimen dan kelas kontrol. Rerata skor post-test siswa kelas eksperimen atau siswa yang mengikuti pembelajaran dengan model pembelajaran Learning Cycle $5 E$ dengan nilai 8,7 lebih tinggi dibandingkan siswa kelas kontrol atau siswa yang mengikuti pembelajaran dengan pendekatan saintifik dengan nilai 6,12 .

Berdasarkan Output Test Statistica menggunakan analisis Uji Non Parametrik mannWhitney untuk data kemampuan komunikasi matematis siswa diperoleh nilai Asymp.Sig 0,000. Sesuai dasar pengambilan keputusan adalah jika nilai pada kolom Asymp.Sig < 0,05 maka Ho ditolak. Karena nilai Asymp.Sig 0,000 < 0,05, maka Ho ditolak dan $\mathrm{H}_{\mathrm{a}}$ diterima. Dengan demikian dapat disimpulkan bahwa terdapat perbedaan kemampuan komunikasi matematis siswa yang diberi model pembelajaran Learning Cycle $5 E$ dengan siswa yang diberi pembelajaran dengan pendekatan saintifik. Dengan kata lain dapat dikatakan bahwa ada pengaruh model pembelajaran Learning Cycle 5E terhadap kemampuan matematis siswa pada materi Barisan apabila dibandingkan dengan pembelajaran saintifik pada materi Barisan di kelas XI SMA Negeri 1 Simpang Mamplam.

\section{KESIMPULAN}

Berdasarkan hasil penelitian dan pembahasan, dapat disimpulkan bahwa: terdapat perbedaan kemampuan komunikasi matematis siswa yang diberi model pembelajaran Learning Cycle 5E dengan siswa yang diberi pembelajaran dengan pendekatan saintifik. Dengan kata lain dapat dikatakan bahwa ada pengaruh model pembelajaran Learning Cycle 5E terhadap kemampuan matematis siswa pada materi Barisan apabila dibandingkan dengan pembelajaran saintifik. Hal ini dapat dilihat dari rerata nila post-test kelas eksperimen dengan menggunakan model pembelajaran Learning Cycle 5E yang meperoleh nilai 8,7 lebih tinggi dibandingkan rerata nilai post-test kelas kontrol dengan menggunakan pendekatan saintifik yang memperoleh nilai 6,12. Penelitian ini dilaksanakan pada kelas XI SMA N 1 Simpang Mamplam.

\section{DAFTAR PUSTAKA}

Apiyati, S. (2016). Penggunaan Model Pembelajaran Kooperatif Tipe Student Teams Achievement Division (Stad) Dalam Upaya Meningkatkan Kemampuan Komunikasi Matematis Pada Pokok Bahasan Pecahan. Jurnal Cakrawala Pendas, 1(2), 55-64. 


\section{Jurnal Pendidikan Matematika Malikussaleh}

Vol 1, Nomor 1, Mei 2021

https://doi.org/10.31949/jcp.v1i2.327

Burais, L., Ikhsan, M., \& Duskri, M. (2016). Peningkatan Kemampuan Penalaran Matematis Siswa melalui Model Discovery Learning. Jurnal Didaktik Matematika, 3(1), 77-86. https://doi.org/10.24815/jdm.v3i1.4639

Ibrahim, \& Suparni. (2008). Strategi Pembelajaran Matematika. Yogyakarta: Sukses Offset.

Kulsum, U., \& Hindarto, N. (2011). Penerapan model learning cycle pada sub pokok bahasan. Jurnal Pendidikan Fisika Indonesia 7, 7, 128-133.

Masitoh, I., \& Prabawanto, S. (2016). Peningkatan Pemahaman Konsep Matematika dan Kemampuan Berfikir Kritis Matematis Siswa Kelas V Sekolah Dasar Melalui Pembelajaran Eksloratif. EduHumaniora | Jurnal Pendidikan Dasar Kampus Cibiru, 7(2), 186. https://doi.org/10.17509/eh.v7i2.2709

NCTM. (2000). Principles and Standards for School Mathematics $\square$ NCTM.

Permendikbud. (2018). Perubahan Atas Peraturan Menteri Pendidikan dan Kebudayaan Nomor 58 Tahun 2014 Tentang Kurikulum 2013 Sekolah Menengah Pertama/Madrasah Tsanawiyah. Sereal Untuk, 51.

PISA. (2012). PISA 2012 Results in Focus.

Tuna, A., \& Kacar, A. (2013). The effect of 5E learning cycle model in teaching trigonometry on students' academic achievement and the permanence of their knowledge. International Journal on New Trends in Education and Their Implications, 4(1), 73-87. 